短 報 Japanese Journal of Health Promotion and Physical Therapy Vol. 6, No. 3 : 139-143, 2016

\title{
足趾把持機能を高めるインソール（靴の中敷き）の開発 \\ Development of Insoles (Shoe Inserts) to Improve the Toe Grip Function
}

\author{
村田 伸 ${ }^{1)}$, 安彦 鉄平 ${ }^{1)}$, 中野 英樹 ${ }^{1)}$, 阪本 昌志 ${ }^{1)}$

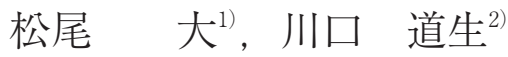

\author{
Shin Murata ${ }^{1)}$, Teppei Abiko ${ }^{1)}$, Hideki Nakano ${ }^{1)}$, Masashi Sakamoto ${ }^{1)}$ \\ Dai Matsuo ${ }^{1)}$, Michio Kawaguchi²)
}

\begin{abstract}
要旨：本研究は，開発した足趾把持機能を高めるインソールを紹介するとともに，その効 果について健常成人女性50名（20.1 1 1. 1歳）を対象に検討した。方法は裸足，一般のイ ンソール靴 (一般靴) と足趾把持機能を高めるインソール靴（開発靴）を履いた 3 条件に おける重心動摇の総軌跡長と外周面積を比較した。多重比較検定の結果, 総軌跡長は裸足 に比べて一般靴と開発靴を履いた状態での值が有意（ $\mathrm{p}<0.01 ）$ に小さく，外周面積は開 発靴を履いた状態での值が裸足よりも有意 $(\mathrm{p}<0.01)$ に小さかった。これらの結果から, 足趾把持機能を高めるインソールの立位バランスに及ぼす一定の効果が示された。本研究 によって，今後介入研究や高齢者を対象にした研究を行う意義が示された。

キーワード：インソール, 足趾把持機能, 重心動摇
\end{abstract}

\begin{abstract}
This study examined the effects of original insoles to improve the toe grip function, involving 50 healthy adult females $(20.1 \pm 1.1)$, with the aim of introducing them. Fluctuations in the center of gravity were measured under 3 conditions to compare the total trace length and outer peripheral area: barefoot, using general insoles (general), and using those to improve the toe grip function (study). In multiple comparisons, the total trace length was significantly shorter under the general and study compared with barefoot condition $(\mathrm{p}<0.01)$. The outer peripheral area was markedly smaller under the study compared with barefoot condition $(\mathrm{p}<0.01)$. It was demonstrated that the insoles to improve the toe grip function positively influence the standing balance. The significance of conducting studies based on intervention or involving the elderly was also indicated.
\end{abstract}

Key words: insoles,toe grip function,center of gravity

受付日：2016年 6 月 8 日，採択日：2016年 7 月 2 日

1) 京都橘大学健康科学部：⿳607-8175 京都市山科区大宅山田34 TEL：075-571-1111

E-mail : muratas3944@gmail.com

Faculty of Health Science, Kyoto Tachibana University, 34 Ohyake yamada, Yamashina-ku, Kyoto-city, Kyoto607-8175, Japan.

2) アシックス商事株式会社企画開発部

Planning and Development Department, ASICS Trading Co., Ltd. 


\section{I 。緒 言}

ヒトが安定した立位姿勢を保持するためには足趾把 持機能, とくに足趾把持力が重要である ${ }^{1,2)}$ 。足趾把持 力とは地面を足趾・足底で掴む力であり，短母趾屈筋， 長母趾屈筋, 虫様筋, 短趾屈筋, 長趾屈筋などの作用 により起こる複合運動である゙”。この足趾把持力は高 齢者の立位バランス ${ }^{4)}$ や転倒 ${ }^{5)}$ との関連性からその重要 性が報告されてきた。さらに, 足趾把持力はトレーニ ングによって強化が可能であり ${ }^{6,7)}$ ，強化することで転 倒者が減少 ${ }^{8}$ することから, 足趾把持力への介入が転 倒予防に有効であることが示されている。

また近年では，足趾把持機能を高める重要性が介護 予防とくにロコモティブシンドロームの予防の観点か

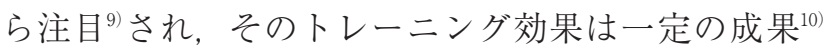
を上げている。ただし, 効果的なトレーニング法であっ ても継続して実施することは難しく，効果の持続性の 問題が指摘 ${ }^{11}$ されている。本研究で紹介するインソー ルを装着した靴を履くことで立位バランスが向上すれ ば, 効果の持続性の問題が解決され, 高齢者の介護予 防に貢献できる可能性が高い。

本研究の目的は，つま先部分を反発性の高い合成繊 維で立体メッシュ構造とし，第一趾から第五趾の基節
骨中央付近に凸形状の盛り上がり（足趾把持バー）を 付けた特殊構造のインソールを紹介するとともに，そ の効果を重心動摇計で測定した総軌跡長と外周面積か ら検証した。なお，本研究は健常成人を対象とした研 究であり，健常高齢者や虚弱高齢者を対象とした研究 を行う前の基礎的研究と位置づけられる。

\section{II. 対象と方法}

\section{1. 対 象}

対象は, K大学理学療法学科に所属する健常女性50 名で, 対象者の平均年齢は20.1 1 1. 1歳, 平均体重は $54.1 \pm 6.2 \mathrm{~kg}$, 平均身長は $160.0 \pm 5.3 \mathrm{~cm}$ であった。 各対象者には研究の趣旨と内容について説明を行い, 理解を得た上で協力を求めた。また，研究への参加は 自由意志であることを口頭と書面で説明し参加の同意 を得た。なお，本研究は京都橘大学研究倫理委員会の 承認を得て行った（承認番号16-1）。

\section{2.インソールの構造と機能}

開発したインソールは，本体部分を合成樹脂発泡体 (エチレン・ビニール・アセテート)，および足先部 （趾骨部）に反発性の高い合成繊維（立体メッシュ）

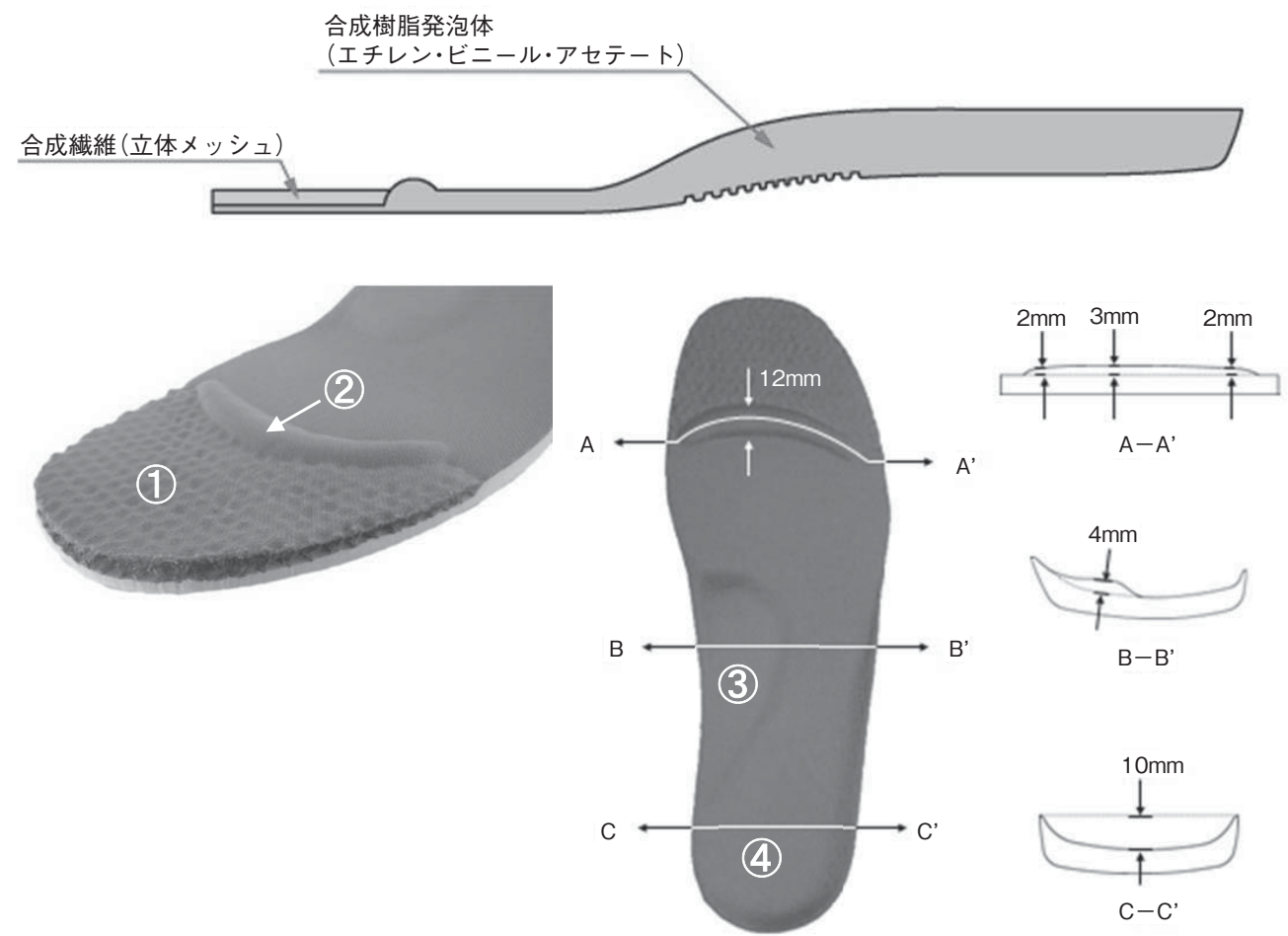

図 1 インソールの構造と機能

(1)立体メッシュ構造：つま先部（趾骨部）は，反発性の高い合成緎維で立体メッシュ構造とした。 (2)足趾把持バー：第一趾から第五趾の基節骨中央付近に凸形状の盛り上がりを取り付けた。

(3)内側縦アーチ：歩行中のミッドスタンス時の内側縦アーチを保持するために内側面を立体形状にした。 (4)踵部の立体形状 : 歩行中のヒールコンタクト時の安定性を向上させる。 
を用いて作成した。構造上の特徵は, 上述した足先部 の立体メッシュ構造と第一趾から第五趾の基節骨中央 付近に設けた凸形状の盛り上がり構造（足趾把持 バー）である。その他, 歩行中のヒールコンタクト時 の安定性を向上させるために踵部を立体形状にし, ミッドスタンス時の内側縦アーチを保持するために内 側面も立体形状にした（図1）。

このインソールを靴に装着して歩行すると, ターミ ナルスタンスに抏いて足先部の合成繊維（立体メッ シュ）が足趾にかかる荷重で沈み込み, 基節骨の中央 付近に設けた足趾把持バーを足趾が認知し, 足趾の反 射的な把持運動（掴む）を促進させる構造とした。な お，立位姿勢においても，前足部に荷重がかかること により足趾の把持運動が促進され，立位バランスが安 定すると考えられる。

\section{3 . 重心動摇の測定方法}

測定には重心動摇計グラビコーダ GP-7（アニマ 社製）を用いて，開眼での足圧重心動摇を計測した。 対象者には，重心動摇計上で両脚立位姿勢をとらせた。 両足の内側縁間を $1 \mathrm{~cm}$ に揃えて足先が前方を向くよ うにし, 膝関節を伸展, 両上肢を体側に付けた姿勢と した。視線は, 対象者の目線の高さに合わせた $2 \mathrm{~m}$ 先のマーカーを注視させた ${ }^{12)}$ 。デー夕は, 初期動摇の 影響が出ないように立位姿勢を5秒間保持した 後 ${ }^{122}, 30$ 秒間の総軌跡長と外周面積について, サンプ リング周期を $20 \mathrm{~Hz}$ として記録した。

測定は裸足，一般のインソール靴（一般靴）と足趾 把持機能を高めるインソール靴（開発靴）を履いた 3 条件に㧈ける重心動摇を計測した。なお，一般靴に装 着しているインソールは, 足先部と足趾把持バー構造 が開発靴と異なるのみで，その他の素材や踵部の立体 形状，掞よび内側縦アーチを保持するための内側面の 立体形状は同様の物を用いた。また，靴の外見や素材 も同一の物とし，アシックス商事製の市販されている 靴を使用した。靴を履いた状態での重心動摇を測定す るにあたり，足長を計測した後，適合する靴を選択し たが，靴のサイズは平均 $23.8 \pm 0.6 \mathrm{~cm}$, 最小 $22.5 \mathrm{~cm}$, 最大 $24.5 \mathrm{~cm}$ であり, $0.5 \mathrm{~cm}$ 刻みで 5 サイズの靴を計 10足使用した。また，それら 5 サイズの靴に適合する インソールも 5 サイズ用意した。なお， 3 条件の測定 順序はランダムに実施した。

\section{4. 統計学的解析法}

裸足および一般靴と開発靴を履いた 3 条件における 総軌跡長と外周面積の比較について, 反復測定分散分 析を用いて検討し，その後，Bonferroni の多重比較検 定を行った。解析にはSPSS Statistics Version22.0を 用い，有意水準を $5 \%$ とした。

\section{III. 結 果}

\section{1. 総軌跡長の比較}

3 条件における総軌跡長の平均值と標準誤差は, 裸 足 $38.89 \pm 1.11 \mathrm{~cm}$, 一 般靴 $34.16 \pm 1.13 \mathrm{~cm}$, 開 発靴 $34.34 \pm 1.26 \mathrm{~cm}$ であった。分散分析の結果，群間に 有意差 $\{\mathrm{F}(2,48)=7.43, \mathrm{p}<0.01\}$ が認められ，多 重比較検定により，一般靴と開発靴を履いた状態での 総軌跡長は，裸足よりも有意 $(\mathrm{p}<0.01)$ に短かった。 一般靴と開発靴の総軌跡長には有意差は認められな かった（図 2 )。

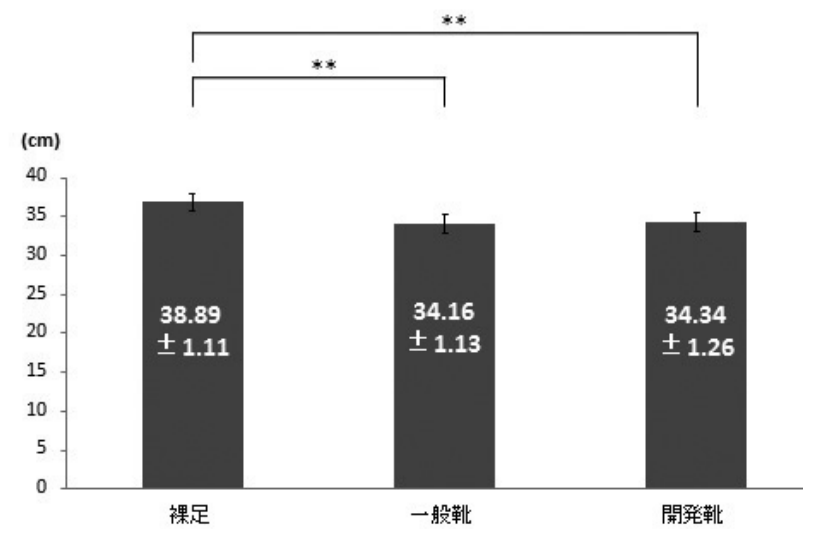

図 2 総軌跡長の比較

反復測定分散分析, Bonferroni多重比較検定 平均土標準誤差 $\quad * * \mathrm{p}<0.01$

\section{2. 外周面積の比較}

3 条件における外周面積の平均值と標準誤差は, 裸 足1. $96 \pm 0.14 \mathrm{~cm}^{2}$ ，一般靴 $1.87 \pm 0.13 \mathrm{~cm}^{2}$ ，開発靴 1.68 $\pm 0.12 \mathrm{~cm}^{2}$ であった。分散分析の結果，群間に有意差

$\{\mathrm{F}(2,48)=4.96, \mathrm{p}<0.05\}$ が認められ，多重比較 検定により，開発靴を履いた状態での外周面積は，裸 足よりも有意 $(\mathrm{p}<0.01)$ に小さかった。その他, 開 発靴と一般靴および一般靴と裸足の外周面積との間に は有意差が認められなかった（図 3 )。

\section{IV. 考 察}

ヒトは，二足で立ち歩行を行うことにより，多くの 生物学的利点を得てきた。ただ，その一方で直立姿 勢は四足位に比べて重心位置が高く，支持基底面が狭 


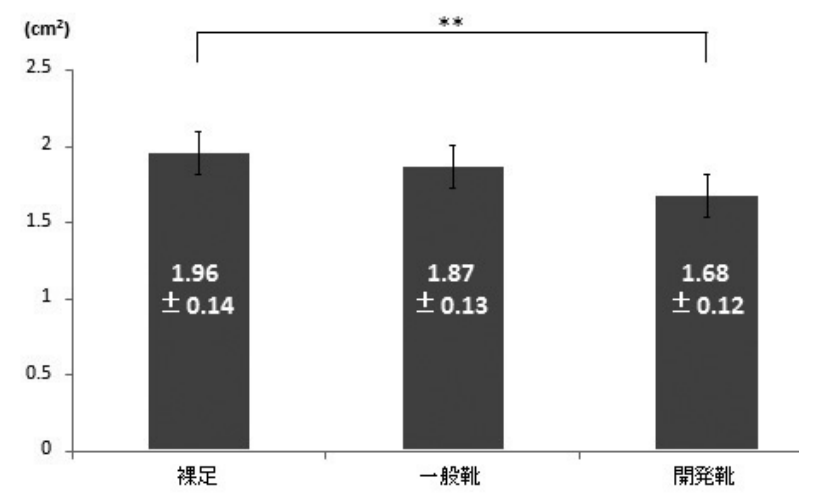

図 3 外周面積の比較

反復測定分散分析, Bonferroni 多重比較検定 平均 \pm 標準誤差 $\quad * * \mathrm{p}<0.01$

いなどの物理的に不安定な条件を持っているため，立 位姿勢においては微妙な身体動摇が生じている。この 身体動摇を捉える一般的な指標として, 重心動摇計を 用いた検査が行われている。

本研究での重心動摇の評価は, 静的立位保持30秒間 における総軌跡長と外周面積により行った。総軌跡長 は床反力作用点の総移動距離を表し, 外周面積は床反 力作用点の移動した外周の線で囲まれる面積を表す。 どちらも重心動摇の程度を表す代表的な值として, 多 くの先行研究で採用されている。本研究によって抽出 された対象者の裸足での総軌跡長は平均 $38.89 \mathrm{~cm}$, 外 周面積の平均は $1.96 \mathrm{~cm}^{2}$ であった。今岡ら ${ }^{13)}$ は, 15施 設に及ぶ多施設共同研究により, 重心動摇の健常者 デー夕を明らかにしている。それによると，20歳から 24歳までの女性169名の60秒間における総軌跡長の平 均值は $67.58 \mathrm{~cm}$ であり, 外周面積の平均值は $2.88 \mathrm{~cm}^{2}$ と報告している。30秒間における総軌跡長の測定值は 60 秒検査のほぼ50\%に相当し, 外周面積の測定值は60 秒検査の $70 \%$ 程度に相当する ${ }^{13)}$ ことから, 今岡らの測 定值を 30 秒間の值に換算すると, 総軌跡長は $33.79 \mathrm{~cm}$, 外周面積は $2.02 \mathrm{~cm}^{2}$ となり, 本研究結果と近似した值 であった。

本研究では, 裸足および一般靴と開発靴を履いた 3 条件に扮ける総軌跡長と外周面積に有意な群間差が認 められた。総軌跡長では, 裸足に比べて一般靴と開発 靴を履いた状態での值が有意に小さく, 安定した立位 姿勢を保持できたことが示唆された。元重ら ${ }^{14)}$ は，健 常成人女性を対象に履物の種類と重心動摇との関係に ついて検討している。彼女らの結果では, 裸足と運動 靴の総軌跡長と外周面積には有意差が認められておら ず, 本研究結果とは異なった。本研究で使用した一般 靴と開発靴には, 踵部の安定性を高めるインソールの
工夫と内側縦アーチを保持するための工夫が施されて おり, これらの機能が身体動摇の小さな摇れを表す総 軌跡長を有意に短縮させたものと推察した。

さらに，開発靴を履いた状態での外周面積は，裸足 での外周面積に比べて有意に小さかった。健常成人に おける静止立位での重心動摇は非常に小さいため, 重 心が一定方向以外に少しでも移動すると, 総軌跡長に 比べて外周面積の変動が大きくなる ${ }^{15)}$ 。今回, 足趾把 持機能を高めるインソールを装着した靴を履くことで, 足趾の把持運動が促進され，不意なふらつきにも瞬時 に姿勢制御機構が作用したと考えられる。ただし，本 研究ではその姿勢制御メカニズムの解明までは至って いない。今後, より詳細な分析が必要であろう。

これらの知見から, 足趾把持機能を高めるインソー ルの一定の効果が示された。ただし，このインソール は, 歩行することで足趾の把持運動が無意識に生じ, 足趾把持機能が高まることで高齢者の転倒予防や介護 予防に貢献することを目的に開発したものである。こ の仮説を検証するためには介入研究を実施する必要が あり，また今回の結果が健常高齢者や虚弱高齢者にも 同様に生じるか否かについて明らかにする必要がある。 本研究によって, 介入研究や高齢者を対象にした研究 を行う意義が示された。

\section{引用文献}

1）井原秀俊：関節トレーニングー神経運動器強調訓練改訂第 2 版. 共同医書, 東京, 1996, 91-92.

2) 村田 伸：開眼片足立ち位での重心動摇と足部機能との関 連一健常女性を対象とした検討一。理学療法科 学, 2004, 19(3): 245-249.

3) 村田 伸, 忽那龍雄 : 足把持力測定の試み一測定器の作成 と測定值の再現性の検討 - . 理学療法科学, 2002, 17 (4) : 243-247.

4）新井智之, 藤田博曉, 細井俊希・他：地域在住高齢者にお ける足趾把持力の年齢, 性別および運動機能との関連. 理 学療法学, 2011, 38(7) : 489-496.

5）村田 伸, 津田 彰：在宅障害高齢者の身体機能 · 認知機 能と転倒発生要因に関する前向き研究. 理学療法 学, 2006, 33(3) : 97-104.

6) 福田 泉, 小林量作: 若年健常者に対する足把持筋力卜 レーニングの効果. 理学療法学, 2008, 35(5)：261-266.

7) 竹井和人, 村田 伸, 甲斐義浩・他：足把持力トレーニン グの効果. 理学療法科学, 2008, 26(1)：79-81.

8）村田 伸, 忽那龍雄 : 在宅障害高齢者に対する転倒予防対 策一足指把持力トレーニング. 日本在宅ケア学会 誌, 2004, 7 (2) : 67-74.

9）湯村良太，石橋英明，藤田博曉：地域在住中高年者におけ る転倒歴とロコモ度テストおよび運動機能測定值との関連. 
理学療法 - 臨床・研究 · 教育, 2016, 23(1) : 40-46.

10）石橋英明, 藤田博暁, 細井俊希・他：ロコモティブシンド ロームの実証データの蓄積 高齢者におけるロコモーショ ンチェックの運動機能予見性およびロコモーショントレー ニングの運動機能増強効果の検証. 運動器リハビリテー ション, 2013, 24(1) : 77-81.

11) Dishman RK, Sallis JF, Orenstein DR: The determinants and interventions for physical activity and exercise. Public Health Rep, 1985, 100(2): 158-171.

12）鈴木淳一, 松永 喬, 徳増厚二 ·他 : 重心動摇検査の Q\& A，手引き (1995). Equilibrium Research55, 1996：6477.

13）今岡 薰, 村瀬 仁, 福原美穂: 重心動摇検査における健 常者データの集計. Equilibrium Research56, 1997：184.

14）元重悠子, 倉田信子：履物の種類による静的・動的重心動 摇の相違に関する基礎的研究. 日本看護医療学会雑 誌, 2011, $13: 42-49$.

15）猪飼哲夫, 辰濃 尚, 宮野佐年：歩行能力とバランス機能 の関係.リハビリテーション医学, 2006, $43:$ 828-833. 